\title{
GOALS AND OBJECTIVES OF EDUCATION FOR SUSTAINABLE DEVELOPMENT AS MODERN CURRICULUM INNOVATION IN SERBIA, MONTENEGRO AND CROATIA
}

$$
\text { UDC 37.011.33(497.11+497.13+497.16) }
$$

\section{Tamara Vukić1, Marija Jovanović1, Dragan Todorović ${ }^{2}$}

${ }^{1}$ University of Niš, Faculty of Philosophy, Department of Pedagogy, Serbia ${ }^{2}$ University of Niš, Faculty of Philosophy, Department of Sociology, Serbia

\begin{abstract}
Education for sustainable development, as an imperative of this day and age, has become an integral part of the curriculum in many education systems. The focus of this paper is education for sustainable development in Montenegro, Croatia and Serbia, with a particular emphasis on the goals and objectives of education for sustainable development. After presenting the specifics of sustainable development at the primary and secondary level of education in these countries, a comparative analysis of learning goals and objectives was conducted between the curriculum of the elective course Education for Sustainable Development in Serbia, interdisciplinary area Education for Sustainable Development in Montenegro and interdisciplinary topic Sustainable Development in Croatia. This comparative analysis established that the goals of education for sustainable development in all three cases are aimed at developing an active and responsible attitude of students towards other people, the environment, taking into account the future perspective, and that the goals and objectives of education for sustainable development in Montenegro and Croatia are more extensive and meaningful compared to the goals and objectives of the elective course Education for Sustainable Development in Serbia. Even though the goals and objectives of the new elective course, interdisciplinary topics and interdisciplinary areas specifically focused on sustainable development represent curriculum innovation in Serbia, Montenegro and Croatia, defining them is only a starting point for activities aimed at educating students to live and work in a modern society that is required to become sustainable.
\end{abstract}

Key words: education for sustainable development, curriculum, Serbia, Montenegro, Croatia.

Received July 28, 2020 / Accepted August 30, 2020

Corresponding author: Tamara Vukić

University of Niš, Faculty of Philosophy, Ćirila i Metodija 2, 18000 Niš, Serbia

E-mail: tamaravukic93@gmail.com 


\section{INTRODUCTION}

A goal as an intention indicates "a point, a limit to be reached, approaching a certain state or relationship to be achieved, a goal to be reached in an activity or behavioural situation" (Милутиновић 2007, 376). In the pedagogical, i.e., educational context, the goals provide an answer to the question of what the school strives to achieve, what it strives for, what it expects and considers desirable and possible in education (Ђорђевић 2014). It is the knowledge, abilities, and other personality traits that are the end goal in the development of students in the process of education (Максимовић 2013). On the other hand, objectives are defined as statements that speak about what a student needs to know, understand and demonstrate after the learning process (Микановић 2014). Therefore, objectives represent "behavioural repertoires that the student acquires through learning; they are predicted at the beginning of the learning process, they are guided by expectations, and later in the course of learning they gradually develop, shape and become real, lasting student achievements" (Бјекић и др. 2012, 150). An important framework for defining the education and learning goals in the context of the new education policy is provided by the concept of sustainable development, which in recent decades has placed focus on the problems facing modern society (Николић и Ђуровић 2012).

Starting from the fact that we are living in times characterized by numerous global issues, such as climate change, gender inequality, human rights violations, hunger, poverty, depletion of natural resources, etc., modern man has faced a challenge: how to save the planet Earth and achieve prosperity, a better and fair life for all people. Thus, the concept of sustainable development was developed, which, through the economic, social and environmental dimensions, provides insight into the problems and consequences of current unsustainable development, and encourages the search for solutions that will lead to future sustainable development.

Sustainable development as a concept ${ }^{1}$ requires consideration of the boundaries of natural resources, ecosystem capacity, and the interaction between social, economic, political and environmental systems (Stanišić 2016). Sustainable development goals are focused on achieving equality with regard to poverty, hunger, education, health care, environmental protection, but also to issues such as sustainable production and consumption, proper governance, open-minded and accountable government and policies that mitigate the effects of conflict, violence and disruption of human rights. The achievement of these goals requires that people become active and responsible citizens, decision-makers who think about the future, with such attitudes and values relying on proper knowledge of the concept of sustainable development (Benavot 2014).

Since these goals define "the type of person to be formed and the type of society that seeks to achieve this" (Ђорђевић 2014, 28), there was a need to redefine the goals and objectives of education and learning, i.e., to align them with modern requirements of sustainable development. This has to do with "shaping the sensibility, the profile of an active, global citizen of the world" (Андевски 2016, 23). Therefore, there was a demand that environmental education, that is, education for environmental protection should be

\footnotetext{
${ }^{1}$ The term sustainable development is linked to the 1980 World Conservation Strategy, which aimed to integrate conservation and development to ensure that changes on the planet ensure allow the survival and wellbeing of all people (IUCN, UNEP and WWF 1980); while sustainable development as a concept was formulated in 1987 in the report "Our Common Future", and is defined as the development that meets the needs of the present without compromising the ability of future generations to meet their own needs (WCED 1987).
} 
supplemented with the problems faced by modern society: human rights, equality, justice, etc., that is, the modern education system demands that the values contained in the sustainable development goals must become an integral part of education programs. A complete shift has been made in this regard, a shift from environmental education to education for sustainable development, which aims to enable current and future generations to live in modern society, to encourage sustainable behaviours, to guide them towards nurturing values such as peace, justice, equality, respect for diversity and respect for nature, the environment in which they live, but also the planet as a whole, and an active and responsible attitude in approaching the issues of modern society with a focus on seeking the solutions for these issues.

In 2017, UNESCO published the Education for Sustainable Development Goals: Learning Objectives, which included 17 global sustainable development goals ${ }^{2}$ and each of them further included goals in the cognitive, socio-emotional and behavioural domain, topics and examples of learning approaches and methods, which serve as guidelines for all those who plan goals of education for sustainable development. The ultimate goal of the publication is to develop sustainability competencies for all learners and empower everyone to contribute to achieving the SDGs (UNESCO 2017). Leicht et al. (2018) indicate that these are competencies such as systemic thinking, joint decision-making and a willingness to take responsibility for present and future generations. Successful realization of the above-mentioned requires that students come into contact with sustainable development. Therefore, this concept has become an integral part of the curriculum in many education systems.

\section{EDUCATION FOR SUSTAINABLE DEVELOPMENT AND THE CURRICULUM}

Education for sustainable development implies the inclusion of core development issues (poverty, peace, local and global responsibility, democracy, justice, human rights, etc.) into the teaching and learning process by using participatory methods that motivate students to change their behaviour towards sustainable development, whereby competencies such as critical thinking, imagining future scenarios and joint decisionmaking are promoted (UNECE 2005a). Education for sustainable development is significantly different from education about sustainable development. When talking about education about sustainable development, one usually refers to the inclusion of new issues or subjects in the curriculum, in order to acquaint students with sustainable development issues (Woo et al., 2012). Education for sustainable development means "promoting the values and behaviours prescribed by sustainable development policies" (Lončar 2011, 249). When it comes to education for sustainable development, education is seen as a tool or instrument for achieving sustainability (Николић 2011).

The transition from education about sustainable development to education for sustainable development can be achieved by innovating curricula and teaching methods (Woo et al. 2012), and, in addition to revising existing curricula, the requirements of the

\footnotetext{
${ }^{2}$ No Poverty; Zero Hunger; Good Health and Well Being; Quality Education; Gender Equality; Clean Water and Sanitation; Affordable and Clean Energy; Decent Work and Economic Growth; Industry, Innovation and Infrastructure; Reduced Inequalities; Sustainable Cities and Communities; Responsible Consumption and Production; Climate Action; Life below Water; Life on Land; Peace, Justice and Strong Institutions; Partnerships for the Goals (UNESCO 2017).
} 
sustainable development concept must be taken into account during curriculum design (Veinović 2017). It is important to keep in mind that sustainable development is not just another topic that needs to be incorporated into the curriculum (Barth and Rieckmann 2012), and that education for sustainable development cannot be reduced to a specific subject which would address the sustainable development concept. It is necessary to reorient the education system, curriculum and teaching methodology towards sustainable living (Vidojević, 2011). Reorienting education to address sustainability is highlighted in Agenda 21, Chapter 36, entitled Promoting Education, Public Awareness and Training. One of the goals of this reorientation is the need to integrate the concept of environment and development into all education programs (UN 1992). Thus, educational communities were required to recognize the knowledge, issues, perspectives, skills and values crucial for sustainable development in each of the dimensions - environmental protection, society, economy, and to integrate them into the curriculum (UNESCO 2012). However, as Milutinović and Nikolić said, strategic documents in the field of sustainable development (national strategies of sustainable development, education strategies for sustainable development, etc.) in South-East Europe "strictly followed the orientation toward the education about sustainable development, instead the education for sustainable development" (Milutinović and Nikolić 2014, 108). Since education for sustainable development promotes values and behaviours that are in line with sustainable development principles, while education about sustainable development implies the acquisition of knowledge about this concept, politics, policies and sustainable development theories (Milutinović and Nikolić 2014), in addition to knowledge about sustainable development, curricula should also include sustainable development skills, perspectives, values and issues (McKeown 2002). However, it is important to emphasize that the distinction between education about sustainable development and education for sustainable development is often not clear enough, and that the terms "green", "environmentally friendly" and "sustainable" are often used as synonyms in the literature, so one dimension of sustainable development may be prevalent in the curriculum (Sherren 2005).

Another big issue is the fact that the integration of sustainable development into the curriculum often comes down to "copying" the curricula of other countries. The Education for Sustainable Development Sourcebook published by UNESCO (2012) emphasized that a properly reoriented curriculum respects local environmental, social, and economic contexts because this ensures that the curriculum is locally relevant and culturally appropriate, and that "copying" the curriculum in the case of education for sustainable development is inappropriate, because in that case national sustainable development goals and the local context will not be well targeted (UNESCO 2012). For this reason, it is important to keep in mind that none of the integration models for sustainable development education goals into the curriculum are perfect, universal and applicable to all situations, systems and school subjects (Veinović 2016). The need to create education programs for sustainable development that are locally (and regionally) relevant is highlighted in the above-mentioned chapter 36 of Agenda 21, where the following is stated: the integration of sustainable development into education programs must take into account the analysis of the causes of crucial environmental and development issues in the local context; when creating national strategies for integrating sustainable development into the education system, it is necessary to do a detailed curriculum analysis with a special focus on environmental and social development issues 
and their socio-cultural and demographic aspects and linkages; when creating work plans in the field of environment, schools should involve students into local and regional research on environmental health and in appropriate activities; it is necessary to find a way to mobilize different sectors of society, in order to assess and meet their educational needs in the field of environment and development; educational tools should include regional issues of sustainable development, with the use of learning materials and resources that are in line with regional requirements, etc. (UN 1992).

Woo et al. (2012) indicate that curriculum design based on sustainability requires a multidisciplinary approach, i.e., the inclusion of different disciplines in solving the problem of sustainability. Similarly, Lozano (2010) says that a more successful inclusion of sustainable development in the curriculum depends on a change of perspective: fragmentation, excessive specialization and reductionism must be replaced by perspectives based on greater balance, synergy, trans-disciplinary approach and holism.

The need for an interdisciplinary and multidisciplinary approach for a thorough understanding of sustainable development is also highlighted in the UNECE Strategy for Education for Sustainable Development (UNECE 2005b), stating that the traditional education focus on individual subjects should be maintained while opening the door to multidisciplinary and interdisciplinary consideration of real-life situations. According to Osman et al. (2017), a valid curriculum is one that provides students with the opportunity to be engaged, to analyse and explore the environment and the world, while building knowledge and skills that will make it easier for them to understand and deal with complex society and environmental issues now and in the future. Therefore, it is necessary to shift the focus away from solely transmitting information, towards dealing with the problems of sustainable development and finding possible solutions (UNECE 2005b), i.e., to "shift the focus from teacher-centered education, i.e., content-centered education, to studentcentered and learning process-centered education" (Vukelić 2020,152). This means that education for sustainable development requires a change in the role of teachers and the development of their professional competencies. Vukelić (2020) points out that the readiness of teachers to implement education for sustainable development requires competencies related to the ability to help those who learn. The teachers' task is to create a student-centered learning environment, to encourage students to be active and cooperative, as well as to base the teaching process on problem-based, anticipatory, innovative, selfregulated and self-directed learning (Ibid).

In addition to the fact that education for sustainable development can be implemented as a part of existing subjects or as an interdisciplinary topic, it can also be implemented as a general framework or platform for the entire school or education system, in order to (re)consider its attitude towards the environment, economy and social community (Benavot 2014). Regardless of how sustainable development is integrated into the curriculum, sustainable development should be its backbone. In other words, it is necessary for education for sustainable development to move from the margins to the center of the curriculum (Jucker 2011), i.e., sustainable development must be the core of the curriculum (Martins et al. 2006).

Starting from the need for sustainable development to become an integral part of the curriculum, education for sustainable development has been implemented in the educational systems of Serbia, Montenegro and Croatia. This paper will present the specifics of education for sustainable development in modern curricula of these countries, as well as a comparative overview of the goals and objectives of elective courses, 
interdisciplinary areas and interdisciplinary topics that are specifically oriented to sustainable development in these education systems.

\section{Methodology}

The aim of the paper is focused on the analysis of education for sustainable development in Serbia, Montenegro and Croatia in order to: (1) consider the specifics of sustainable development in primary and secondary schools in education systems of these countries, and (2) conduct a comparative analysis of learning goals and objectives which are contained in the curricula specifically focused on sustainable development: the elective course Education for Sustainable Development in Serbia, interdisciplinary area Education for Sustainable Development in Montenegro and the interdisciplinary topic Sustainable Development in Croatia. The theoretical analysis method was used, where the primary documentation sources were used as samples for the conducted analysis, as follows: guidelines on curricula for primary and secondary schools in Serbia, and especially Guidelines on the curriculum for the first grade of grammar school (Serbia), Interdisciplinary areas in subject curricula: general grammar school and Methodological instructions for the implementation of the Education for Sustainable Development program (Montenegro), and Decision on the adoption of the curriculum for the interdisciplinary topic Sustainable development for primary and secondary schools in the Republic of Croatia (Croatia). The following comparative analysis components were used: goals and objectives of the elective course Education for Sustainable Development for the first grade of grammar school (Serbia), interdisciplinary area Education for Sustainable Development (Montenegro) and interdisciplinary topic Sustainable Development (Croatia). These were taken as key didactic categories that allow us to better understand the specifics, and the similarities and differences between these courses/interdisciplinary areas/topics that are specifically oriented towards sustainable development.

\section{RESULTS AND DISCUSSION}

\subsection{Specifics of education for sustainable development in Serbia, Montenegro and Croatia}

Viewed from the perspective of education for sustainable development, one of the main goals of primary education in Serbia is "developing awareness of the importance of sustainable development, protection and preservation of nature and the environment and environmental ethics, protection and welfare of animals" (Правилник о плану наставе и учења... 2017, 2). Moreover, other goals have been set that can be linked to sustainable development, such as developing competencies for coping with and active participation in modern society, developing feelings of solidarity, understanding and constructive cooperation, fostering friendship, developing and respecting racial, national, cultural, language, religious, gender, and age equality, developing tolerance and having respect for diversity (Ibid). However, it is important to emphasize that primary education does not include any special subject that refers exclusively to sustainable development, students are actually introduced to this topic within other subjects. These contents are studied in 
the subjects: World around us ( $1^{\text {st }}$ and $2^{\text {nd }}$ grade), Nature and society ( $3^{\text {rd }}$ and $4^{\text {th }}$ grade), Civic education $\left(1^{\text {st }}, 2^{\text {nd }}, 3^{\text {rd }}, 4^{\text {th }}, 5^{\text {th }}, 6^{\text {th }}, 7^{\text {th }}\right.$, and $8^{\text {th }}$ grade), Geography, Biology, Engineering and Technology $\left(5^{\text {th }}, 6^{\text {th }}, 7^{\text {th }}\right.$, and $8^{\text {th }}$ grade $)$, Physics $\left(6^{\text {th }}, 7^{\text {th }}\right.$ and $8^{\text {th }}$ grade) and Chemistry ( $7^{\text {th }}$ and $8^{\text {th }}$ grade). ${ }^{3}$ Also, foreign languages curriculum for the first and second cycle of primary education (Ibid) includes certain thematic areas that belong to the field of sustainable development.

In addition to the general education goals, secondary vocational education also includes individual goals that are related to sustainable development: ensuring a motivating and safe environment; developing and practicing healthy lifestyles; developing awareness of the importance of sustainable development and environmental protection (Правилник о изменама и допунама... 2017). In most educational profiles in secondary vocational schools in Serbia, students are introduced with the sustainable development topic within the Ecology and Environmental Protection subject. Moreover, according to their specifics, some areas, i.e., educational profiles include several subjects specifically dedicated to sustainable development. It is important to emphasize the following ones: Sustainable development in construction (geodesy and construction), Sustainable development (chemistry, non-metals and graphics), Energy efficiency and sustainable development (geology, mining and metallurgy), Sustainable design (forestry and wood processing) (Правилници о плану и програму наставе и учења у средњим стручним школама... 2015, 2017, 2018). Moreover, there are also other subjects which cover sustainable development topics, but they are mostly focused on environmental protection: Health and environmental protection (geodesy and construction), Climatology, Meteorology of air pollution (mathematics), Renewable energy sources (electrical engineering and informatics); Protection of work and natural environment, Environmental protection in the oil industry, Sources of environmental pollution, Water pollution and protection, Soil pollution and protection, Air pollution and protection (chemistry, non-metals and graphics), Environmental protection (mechanical engineering and metal processing), Renewable energy sources (geology, mining and metallurgy), etc. (Правилници о плану и програму наставе и учења у средњим стручним школама... 2010, 2013, 2015, 2017, 2018).

When it comes to general secondary education, to grammar schools, one of the goals is dedicated to sustainable development: "developing awareness of the importance of sustainable development, protection and preservation of nature and environment and environmental ethics" (Правилник о програму наставе и учења за први разред гимназије 2018, 94). Students are introduced to sustainable development in Geography, Biology and Chemistry classes, but also in the multidisciplinary elective course Education for Sustainable Development, which, starting from the 2018/2019 school year, has been part of the curriculum for all four grades of grammar school. This course is implemented through group work of students who, according to their interests and guided by the content presented by the teacher, choose a topic to explore (e.g., students can visit an institution that adheres to sustainability principles, they can collect data from websites and relevant literature, or examine attitudes of peers and fellow citizens, etc.). Based on the obtained results, the project problem is defined, and all students participate in its implementation. The aim of the project is to reflect on one's behaviour in the context of sustainable development, as well as to undertake and propose activities aimed at the well-

\footnotetext{
${ }^{3}$ For more details please refer to guidelines on the curriculum for primary school from 2017, 2018 and 2019 , which we refer to in the paper.
} 
being of the environment (e.g., information on water saving, film on illegal dumps, letter to the mayor to find a place for electronic waste disposal, etc.) (Ibid).

In Montenegro, contents in the field of sustainable development have been introduced as an interdisciplinary area of Education for Sustainable Development through the entire general education curriculum (primary school, grammar school and general education subjects in secondary vocational schools), emphasizing that the focus remains on individual subjects, while simultaneously analysing the problem from different perspectives (Čabrilo et al. 2015). This interdisciplinary area was adopted by the National Council for Education in 2015. It is realized on the basis of cross-curricular topics (Climate change, Green economy, Environmental protection, Spatial evaluation and planning - sustainable cities and settlements, Biodiversity, Health education, Education for and about human rights, Entrepreneurial learning), in accordance with the defined goals, contents, interdisciplinary correlations, learning objectives and didactic recommendations given for each of them. When planning lessons, the teacher starts from the goals of his/her subject and includes in the annual plan those operational goals of education for sustainable development, which can be achieved in the same way as the goals of the subject. The identification of the goals of education for sustainable development is supported by correlations which indicate the connection between the goals of interdisciplinary topics and individual subjects (Čabrilo et al. 2015).

Starting from the 2019/2020 school year, in primary and secondary schools in Croatia, the curriculum for the interdisciplinary topic Sustainable Development, which is incorporated into all education cycles, has been applied ${ }^{4}$. The topic is focused on all three dimensions of sustainable development (society, economy, environmental protection) in order for students to acquire knowledge about the diversity of nature, the need for sustainable management of natural resources, personal and shared rights and responsibilities, etc., skills to act towards personal and general well-being, values such as solidarity and responsibility, and to develop a personal identity while respecting diversity (Odluka o donošenju kurikuluma... 2019).

Within the domains Connectivity (fundamental principles of sustainability and interdependence in ecosystems), Action (knowledge and skills for a sustainable living) and Wellbeing (responsibility and rights in the context of well-being for all people, environment and future generations) key contents are presented (mandatory and recommended), as well as educational expectations and recommendations (correlations) for their realization in each education cycle (Ibid).

\subsection{Goals and objectives of education for sustainable development in Serbia, Montenegro and Croatia - a comparative review}

As stated in the methodological part of the paper, the comparative review of education for sustainable development in Serbia, Montenegro and Croatia is focused on presenting and analysing the goals and objectives of the elective course, interdisciplinary area and interdisciplinary topic specifically oriented toward sustainable development. The elective course in Serbia, Education for Sustainable Development, aims to develop among the students a "critical, active and responsible attitude towards themselves and the

${ }^{4} 1^{\text {st }}, 2^{\text {nd }}$ and $3^{\text {rd }}$ cycle refer to primary education, $4^{\text {th }}$ cycle includes $1^{\text {st }}$ and $2^{\text {nd }}$ grade of four-year-long high school, and $1^{\text {st }}$ grade of three-year-long high school education; the $5^{\text {th }}$ cycle includes the remaining grades of four-year and three-year-long high school education 
environment in which they live and to see the present through the perspective of the future" (Правилник о програму наставе и учења за први разред гимназије 2018, 230), exploring the interdependence between human activities and their immediate environment. Within the education system of Montenegro, the goal of education for sustainable development is more thorough, pointing to the need for active participation of students in the development not only of their immediate environment, but also their country, and the development at the global level. The Methodological Guide for the Implementation of the Education for Sustainable Development program points out that the goals and principles of education for sustainable development largely coincide with the general education goal in Montenegro, which should enable students to "actively participate and contribute to social, economic and cultural development of their country, their birth place, and also the planet as a whole" (Čabrilo et al. 2014, 29). When it comes to the interdisciplinary topic Sustainable Development, no general goal is given; however, several education goals are presented in the Decision on the adoption of the curriculum for the interdisciplinary topic Sustainable Development for primary and secondary schools in the Republic of Croatia (Narodne novine 7/2019): (1) to acquire knowledge about nature and understand the relationship between people and the environment, develop critical thinking, personal and social responsibility; (2) to get acquainted with the causes and consequences of human impact on nature in order to influence the development of thinking, especially creative, and problem-oriented thinking; (3) to develop solidarity and empathy, as well as responsibility and motivation to act correctly in relation to nature and other people; (4) an active approach in school and community with the aim of identifying needs, devising solutions and specific contribution to the community, and (5) to encourage thinking about future generations and develop responsibility towards them. It can be concluded that these individual goals are partially similar to the goals of education for sustainable development in Serbia and Montenegro. Their similarity is reflected in the emphasis on the need for an active and responsible attitude of the individual towards the environment and other people, today and in the future, which is at the same time the main precondition for development that can be considered sustainable. On the other hand, it can be noticed that the goal of education for sustainable development is most specifically defined in Serbia and is not oriented towards the global context as is the case in Montenegro, nor towards the development of empathy and broad social responsibility as in Croatia. Objectives of the interdisciplinary topic Sustainable development in Croatia are defined through educational expectations by education cycles and domains: connectivity, action, well-being. The main objectives of primary education in these domains are oriented towards: recognizing the importance of well-intentioned actions towards people and nature; consideration of the impact of the use of different energy sources on the environment and people; analyzing ecosystem values and principles; explaining the connection between economic activities and the situation in the environment and society; assessing the importance of righteousness in society, etc. (Odluka o donošenju kurikuluma... 2019). The outcomes of secondary education for sustainable development in Croatia are given in Table 1, for the purposes of a clearer overview and comparison with the same level of education in Serbia and Montenegro.

As we can see from the table, the objectives of Education for Sustainable Development at this level of education in Croatia are focused on competencies in the fields of environmental protection (natural balance, ecosystems), economy (production and consumption, economic models) and society (identity, social justice, social differences). 
Table 1 The outcomes of secondary education for sustainable development in Croatia

\begin{tabular}{|c|c|c|c|}
\hline Domain & Connectivity & Action & Wellbeing \\
\hline 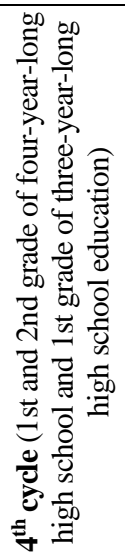 & $\begin{array}{l}\text { - distinguishes personal from } \\
\text { collective identity, and has a } \\
\text { sense of belonging to } \\
\text { humanity } \\
\text { - explains the importance of } \\
\text { establishing natural balance } \\
\text { - assesses how the state of the } \\
\text { ecosystem affects the quality } \\
\text { of life } \\
\text { - collects, analyses and } \\
\text { evaluates data on the impact } \\
\text { of the economy, state policy } \\
\text { and everyday consumption } \\
\text { of citizens on sustainable } \\
\text { development }\end{array}$ & $\begin{array}{l}\text { - acts in accordance } \\
\text { - with the principles of } \\
\text { sustainable } \\
\text { development with the } \\
\text { aim of protecting nature } \\
\text { and environment } \\
\text { - acts in accordance with } \\
\text { the principles of } \\
\text { sustainable } \\
\text { development with the } \\
\text { aim of promoting social } \\
\text { justice }\end{array}$ & $\begin{array}{l}\text { - considers the importance of } \\
\text { sustainable development for } \\
\text { the common good } \\
\text { - analyses indicators of } \\
\text { quality of life in a society } \\
\text { and explains differences } \\
\text { between societies } \\
\text { - analyses and compares the } \\
\text { causes and consequences of } \\
\text { social differences in some } \\
\text { societies from the point of } \\
\text { view of individual's well- } \\
\text { being } \\
\text { - describes the impact of } \\
\text { different economic models } \\
\text { on welfare }\end{array}$ \\
\hline 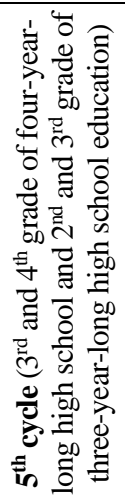 & $\begin{array}{l}\text { - critically considers the } \\
\text { connection between one's } \\
\text { own way of life and the } \\
\text { impact on the environment } \\
\text { and people } \\
\text { - analyses the principles of } \\
\text { sustainable production and } \\
\text { consumption } \\
\text { - analyses power relations at } \\
\text { different levels of } \\
\text { government and explains } \\
\text { their impact on sustainable } \\
\text { development }\end{array}$ & $\begin{array}{l}\text { - critically reflects on the } \\
\text { impact of our actions } \\
\text { on Earth and humanity } \\
\text { - designs and uses } \\
\text { innovative and creative } \\
\text { forms of action to } \\
\text { achieve sustainability } \\
\text { - participates in activities } \\
\text { inside and outside of } \\
\text { school aimed at the } \\
\text { common good }\end{array}$ & $\begin{array}{l}\text { - explains the connection } \\
\text { between resource } \\
\text { consumption and equitable } \\
\text { distribution to ensure the } \\
\text { common good } \\
\text { - suggests ways to improve } \\
\text { personal and general well- } \\
\text { being }\end{array}$ \\
\hline
\end{tabular}

Source: Odluka o donošenju kurikuluma za međupredmetnu temu Održivi razvoj za osnovne i srednje škole u Republici Hrvatskoj. Narodne novine 7/2019.

Regarding the objectives for the interdisciplinary area of Education for Sustainable Development in Montenegro, no general expectations are given, but for each of the proposed topics (Climate change, Green economy, Environmental protection, Spatial evaluation and planning - sustainable cities and settlements, Biodiversity, Health education, Education for and about human rights, Entrepreneurial learning) operational goals are suggested.

In Serbia, within the elective course Education for Sustainable Development, general objectives (objectives at the end of the course) and special objectives for each of the planned topics are suggested: "Water", "Air" and "Sustainable Cities and Settlements". At the end of the elective course, students will be able to critically consider the impact of man on the environment, and to distinguish between positive and negative attitudes towards it, and predict the future consequences of irresponsible behaviour, as well as to reduce their own negative impact on the environment. Moreover, students will be able to consider the needs of modern people from the perspective of sustainable development and to participate in activities aimed at improving the quality of life in the environment (Правилник о програму наставе и учења за први разред гимназије 2018). 
Table 2 shows those operational goals related to grammar school education in Montenegro (Čabrilo et al. 2014, 29) and education objectives in Serbia (Правилник о програму наставе и учења за први разред гимназије 2018) for the same thematic areas.

The topics "Water" and "Air", which are included in the elective course Education for Sustainable Development (Serbia) are presented as sub-topics within the topic "Environmental Protection" in the interdisciplinary area Education for Sustainable Development (Montenegro), while the topic "Sustainable Cities and settlements" is part of the topic "Spatial evaluation and spatial - sustainable cities and settlements".

Table 2 Learning objectives and operational goals in Serbia and Montenegro

\begin{tabular}{|c|c|}
\hline $\begin{array}{c}\text { Serbia } \\
\text { Elective course } \\
\text { Education for sustainable development }\end{array}$ & $\begin{array}{c}\text { Montenegro } \\
\text { Interdisciplinary area } \\
\text { Education for sustainable development }\end{array}$ \\
\hline Learning objectives & Operational goals \\
\hline & WATER \\
\hline $\begin{array}{l}\text { At the end of the first grade, the student will } \\
\text { be able to: } \\
\text { - participate in the adoption of rules of } \\
\text { behaviour and work in groups } \\
\text { - explain the importance of the concept of } \\
\text { sustainable development in modern } \\
\text { society } \\
\text { - rationally use and protect water from } \\
\text { pollution } \\
\text { - connect the survival of wildlife and water } \\
\text { quality } \\
\text { - assess the consequences of human } \\
\text { activities that lead to water pollution } \\
\text { - assess the pros and cons of household } \\
\text { chemicals and advocates for their reduced } \\
\text { use }\end{array}$ & $\begin{array}{l}\text { - Students are supposed to: } \\
\text { - understand that access to safe drinking water and } \\
\text { sanitation facilities are one of the fundamental human } \\
\text { rights } \\
\text { - learn that water is a global issue and that everyone needs } \\
\text { a responsible, safe and continuous water supply } \\
\text { - view water as a natural resource for generation of energy } \\
\text { - understand the importance of using water for agricultural } \\
\text { and industrial purposes } \\
\text { - understand that ecosystem change has a key role to play } \\
\text { in maintaining water quantity and quality } \\
\text { - learn about chemical ways to purify water } \\
\text { - propose scientific concepts for efficient water use that } \\
\text { are necessary for a sustainable future } \\
\text { - have personal responsibility for the use of water in the } \\
\text { local community, participate in local actions and make a } \\
\text { positive impact to water conservation, etc. }\end{array}$ \\
\hline \multicolumn{2}{|r|}{ AIR } \\
\hline $\begin{array}{l}\text { - predict the consequences that the use of } \\
\text { different types of energy sources used for } \\
\text { heating/cooling has on air quality } \\
\text { - critically analyse monthly energy } \\
\text { consumption in his/her household } \\
\text { - find and evaluates relevant data related to } \\
\text { air quality in his/her surroundings } \\
\text { - discuss the impact of various factors on } \\
\text { air pollution and human health } \\
\text { - arguably advocate for the improvement of } \\
\text { air quality in his/her immediate } \\
\text { surroundings by undertaking activities at } \\
\text { home, in school and environment }\end{array}$ & $\begin{array}{l}\text { - understand the importance of air for human health, } \\
\text { ecosystems and materials } \\
\text { - understand the functions of air } \\
\text { - know the sources of pollution (natural and artificial) } \\
\text { - analyse the impact of various pollutants on air quality } \\
\text { - compare air quality in open and closed spaces } \\
\text { - propose measures to reduce anthropogenic air pollution } \\
\text { - familiarize themselves with measures to protect the air } \\
\text { from pollution } \\
\text { - critically analyse air quality in different parts of } \\
\text { Montenegro }\end{array}$ \\
\hline
\end{tabular}




\begin{tabular}{|c|c|}
\hline $\begin{array}{c}\text { Serbia } \\
\text { Elective course } \\
\text { Education for sustainable development }\end{array}$ & $\begin{array}{c}\text { Montenegro } \\
\text { Interdisciplinary area } \\
\text { Education for sustainable development }\end{array}$ \\
\hline Learning objectives & Operational goals \\
\hline \multicolumn{2}{|c|}{ SUSTAINABLE CITIES AND SETTLEMENTS } \\
\hline $\begin{array}{l}\text { - explain how the basic needs of the people } \\
\text { around him/her are met } \\
\text { - connect the main principles of sustainable } \\
\text { planning and development with the } \\
\text { possibilities of improving the sustainability - } \\
\text { of the place where he/she lives } \\
\text { - critically analyse the decisions of the local } \\
\text { community on the use, protection and } \\
\text { preservation of the common space } \\
\text { - compare his/her own needs with the needs - } \\
\text { of other people living in the same } \\
\text { settlement } \\
\text { - promote the preservation of the immediate } \\
\text { environment through his/her own activities " } \\
\text { - use his/her own activities to promote } \\
\text { sustainable space planning in his/her } \\
\text { immediate environment }\end{array}$ & $\begin{array}{l}\text { - become familiar with the characteristics of sustainable } \\
\text { cities and settlements } \\
\text { - identify the characteristics and principles of sustainable } \\
\text { community development } \\
\text { - raise awareness of a holistic approach to planning and } \\
\text { building sustainable cities and urban settlements } \\
\text { - recognize different approaches to sustainable community } \\
\text { movement and contribute to the sustainable development } \\
\text { of the community and local population } \\
\text { - analyse the functioning of cities in the past, present and } \\
\text { predict the functions of future cities - learn how to make } \\
\text { decisions on public spending to provide public places } \\
\text { and facilities for recreation } \\
\text { - raise awareness of improving local communities and } \\
\text { cities to become more pleasant places to live (healthy, } \\
\text { attractive and economically successful) } \\
\text { - recognize the ways in which the environment can } \\
\text { respond to the needs of community diversity, etc. }\end{array}$ \\
\hline
\end{tabular}

Sources: “Правилник о Програму наставе и учења за први разред гимназије” 2018, 230; Cabrilo et al. 2014, 24-27, 32-35.

Despite the essentially same objectives, i.e., operational goals related to water protection, identification of air pollutants, analysis of air quality and measures for its protection, and understanding of the relationship between sustainable cities and settlements and people's needs, local community responses to these and individuals' actions taken, operational goals for the interdisciplinary field of Education for Sustainable Development (Montenegro) are much broader because it is an interdisciplinary area that requires a holistic, interdisciplinary approach, while providing the opportunity to consider various aspects of sustainable development (from different perspectives) in the context of the presented topics.

A broader analysis of the presented operational objectives and consideration of the specific thematic framework in Montenegro (human rights, health education, entrepreneurial learning, green economy) indicates their orientation not only towards the dimension of environmental protection, but also the social and economic dimension of sustainable development.

Despite the specific framework of presenting the objectives of education for sustainable development in these educational systems, it can be concluded that the objectives of education for sustainable development in Serbia, Montenegro and Croatia are oriented to all three dimensions of sustainable development (economy, society, environment).

Previous studies in the field of education for sustainable development in Serbia, Montenegro and Croatia are mainly focused on (1) the representation, role and importance of education for sustainable development (Андевски 2016; Borić et al. 2008; Jelić-Muck and Pavić-Rogošić 2002), (2) content at individual levels and in individual education systems (Andevski 2006; Andevski and Kliček 2008; Kostović-Vranješ 2015; Минић и Јовановић 2019; Veinović 2016; Вукић 2019) and (3) teacher education and implementation of this concept in schools (Anđić 2015; Nikolić et al. 2017; Орловић-Ловрен 2016; Raditya-Ležaić et al. 2018; Веиновић 2015), etc. Sustainable development is presented from a comparative 
perspective in a paper dedicated to the national strategies of sustainable development of Serbia, Montenegro and Croatia (Надић 2012). However, comparative research on education for sustainable development, and more specifically - the goals and objectives of education for sustainable development are lacking in the countries of the region, so it is not possible to compare and discuss the presented results in the context of similar research.

\section{CONCLUSION}

Starting from the fact that education at the international level has been identified as a precondition for achieving sustainable development, many countries have incorporated it into their education systems. This paper presents the specifics of sustainable development at the primary and secondary school level in the education systems of Serbia, Montenegro and Croatia and provides a comparative overview of the goals and objectives of the elective course and interdisciplinary topics/areas specifically oriented to sustainable development. The subjects of the comparative analysis were: (1) the elective course Education for Sustainable Development in Serbia; (2) interdisciplinary area Education for Sustainable Development in Montenegro and (3) interdisciplinary topic Sustainable Development in Croatia.

In Serbia, students are introduced to the concept and characteristics of sustainable development in primary and secondary schools, in accordance with the field of education, as part of subjects such as Nature and society, Biology, Chemistry, Geography, Civic education, etc. The subject specifically focused on sustainable development called Education for Sustainable Development has become available as an elective course from 2018/2019 school year to grammar school students.

In Montenegro and Croatia, sustainable development is an integral part of the curriculum, as an interdisciplinary area in primary and secondary schools.

The main unit of the comparative analysis of education for sustainable development in these education systems were the goals and objectives as the main didactic categories. The analysis has shown that the goals of education for sustainable development in all three countries are aimed at developing an active and responsible attitude of students towards other people and the environment, taking into account the perspective of the future. When it comes to education objectives, within the elective course Education for Sustainable Development (Serbia), general objectives were presented that refer to a critical consideration of the relationship between man and the environment with an effort to reduce the negative impact of man on the environment and improve quality of life; however, specific objectives for the topics "Water", "Air" and "Sustainable cities and settlements" were provided as well.

The comparison of specific objectives and operational objectives for grammar schools (for the same topics as in the curriculum of the interdisciplinary area of Education for Sustainable Development in Montenegro) suggests that in Montenegro the operational objectives are much broader because it is an interdisciplinary area, which requires a broader approach to the given topics, from the perspective of different subjects, i.e., disciplines. The curriculum for Montenegro does not provide general education objectives.

In Croatia, education objectives are presented through educational expectations by education cycles and domains (connectivity, action, well-being) in the interdisciplinary topic Sustainable Development. The presented objectives refer to both primary and secondary schools and are much more extensive in comparison to the education objectives provided 
for the elective course Education for Sustainable Development in grammar schools in Serbia.

Despite the fact that education for sustainable development as an integral part of the curriculum in the education systems of Serbia, Montenegro and Croatia is an innovation (in Serbia, the elective course has been available since 2018, the interdisciplinary area was introduced in Montenegro in 2015, while in Croatia that happened during the 2019/2020 school year), these efforts represent a significant step forward in preparing students for modern society and the society of the future, as future representatives of civic activism who will responsibly and conscientiously seek answers to the many problems of modern civilization.

It is important to emphasize that the implementation of education for sustainable development in the given countries is in line with the two main tendencies of integrating sustainable development into the curricula as suggested by Ceulemans and De Prins (2010). This is a horizontal and vertical integration of sustainable development, where horizontal integration implies a kind of intertwining of different subjects with sustainable development, as in the case of Montenegro and Croatia, while vertical integration refers to the design of specific subjects focusing on sustainable development, as in the case of Serbia. Moreover, for the successful establishment of a new, sustainable, education system, it is necessary to be guided by recommendations for the improvement of existing education. Such are, for example, the guidelines given in the National Strategy for Sustainable Development of the Republic of Serbia, which, we believe, also apply to other countries. Thus, the Strategy recommends sustainable education in the Republic of Serbia that will be "competitive in accordance with the scientific, economic and technological potentials of the Republic of Serbia; accessible to all, especially children and members of socially vulnerable social groups; adaptable and in line with labour market needs; attractive enough and in line with socio-economic changes; included in the European education system; subject to modern financing based on the model of the European financial system; based on the system of modern management, certification, licensure and accreditation" (Влада Републике Србије 2008 , 37). Given the fact that the presented elective course and interdisciplinary areas/topics represent an innovation in the curricula of the given countries, their improvement and development can be expected in terms of expanding and deepening the defined goals, content and outcomes.

The results obtained should be viewed as a potential to improve this area of education in terms of regional integration in relation to educational activities regarding this issue that is significant at the global level. Collaboration and coworking should be based on the adoption and implementation of positive experiences and the prevention of identified risks. Therefore, this comparative overview can serve as a foundation for mutual empowerment in the process of developing more modern and thorough approaches to education for sustainable development. Moreover, it should be emphasized that the mere fact that comparative studies of goals and objectives of education for sustainable development in the countries of the region do not exist further suggests that this paper is a valuable attempt to initiate the idea of related studies and the need to conduct research on other important issues related to this field, which were only mentioned in this paper. 


\section{REFERENCES}

Андевски, Милица Ј. “Одрживо еколошко образовање - перспектива за промену културе учења”. Иноваиије у настави 29 (2016): 16-31. doi: 10.5937/inovacije1604016A.

Andevski, Milica i Tamara Kliček. "Održivo obrazovanje - put u globalno društvo znanja.” U Životna sredina danas, uredio L. Jovanović, 247-252. Beograd: Naučno-stručno društvo za zaštitu životne sredine Srbije, Ekologica, 2008.

Andevski, Milica. Ekologija i održivi razvoj - na putu ka društvu učenja. Novi Sad: CEKOM-books d.o.o., 2006.

Anđić, Dunja. "Doprinosi razvoju kompetencija učitelja osnovnih škola u odgoju i obrazovanju za održivi razvoj”. Napredak: časopis za pedagogijsku teoriju i praksu 156 (2015): 367-383.

Barth, Matthias, and Marco Rieckmann. "Academic Staff Development as a Catalyst for Curriculum Change Towards Education for Sustainable Development: An Output Perspective". Journal of Cleaner Production 26 (2012): 28-36. doi:10.1016/j.jclepro.2011.12.011.

Benavot, Aaron. Education for Sustainable Development in Primary and Secondary Education, 2014. Accesed July 23, 2019.

Бјекић, Драгана, Милица Вучетић и Лидија Златић. “Исходи образовања наставника према дводимензионалном моделу таксономије Блумових сарадника.” У Настава и учење - циљеви, стандарди и исходи, уредила Снежана Маринковић, 147-164. Ужице: Учитељски факултет у Ужицу, 2012.

Borić, Edita, Ranka Jindra i Alma Škugor. "Razumijevanje i primjena sadržaja cjeloživotnog učenja za održivi razvoj”. Odgojne znanosti 10 (2008): 315-327.

Ceulemans, Kim, and Marijke De Prins. "Teacher's Manual and Method for SD Integration in Curricula". Journal of Cleaner Production 18 (2010): 645-651.

Čabrilo, Nevena, Snežana Grbović, Zoran Lalović, Radoje Novović, Jasmina, Đorđević i Milica Vušurović. Međupredmetne oblasti u predmetnim programima: opšta gimnazija. Podgorica: Zavod za školstvo, 2014.

Čabrilo, Nevena, Zoran Lalović, Srna Sudar i Mira Vasiljević. Metodološko uputstvo za implementaciju programa Obrazovanje za održivi razvoj. Podgorica: Zavod za školstvo, 2015.

Ђорђевић, Јован. “Значај и проблеми циљева и задатака образовања и васпитања у савременој школи”. Годишњак Српске академије образовања X (2014): 25-44.

Đukić, Petar. “Održivi razvoj - integralno razumevanje i primena u univerzitetskoj nastavi u Srbiji”. U Univerzitet $i$ održivi razvoj, uredio Čedomir Čupić, 63-84. Beograd: Fakultet političkih nauka Univerziteta u Beogradu i Centar za ekološku politiku i održivi razvoj, 2011.

IUCN, UNEP and WWF. World Conservation Strategy, 1980. Accessed July 16, 2020. https://portals.iucn.org/ library/efiles/documents/wcs-004.pdf

Jelić-Muck, Višnja, and Lidija Pavić-Rogošić. Pregled i ocjena napretka provedbe Agende 21 u Hrvatskoj. Radni materijal za raspravu, 2002. Accessed July 23, 2019. http://www.odraz.hr/media/21885/agenda21.pdf.

Jucker, Rolf. "ESD between Systemic Change and Bureaucratic Obfuscation: Some Reflections on Environmental Education and Education for Sustainable Development in Switzerland". Journal of Education for Sustainable Development 5 (2011): 39-60. doi: 10.1177/097340821000500109.

Kostović-Vranješ, Vesna. "Baština - polazište za promicanje odgoja i obrazovanja za održivi razvoj". Školski vjesnik: časopis za pedagogijsku teoriju i praksu 64 (2015): 439-452.

Leicht, Alexander, Julia Heiss, and Won Jung Byun. Issues and Trends in Education for Sustainable Development. Place de Fontenoy, Paris: UNESCO, 2018.

Lončar, Jelena. "Obrazovanje za održivi razvoj na fakultetima društveno-humanističkih nauka". U Univerzitet $i$ održivi razvoj, uredio Čedomir Čupić, 241-261. Beograd: Fakultet političkih nauka Univerziteta u Beogradu i Centar za ekološku politiku i održivi razvoj, 2011.

Lozano, Rodrigo. "Difusion of Sustainable Development in Universities' Curricula: An Empirical Example from Cadiff University”. Journal of Cleaner Production 18 (2010): 637-644. doi: 10.1016/j.jclepro.2009.07.005.

Максимовић, Александра. “Однос између циљева васпитања и образовања и евалуације исхода”. Иновације у настави 26 (2013): 93-99.

Martins, António A., Teresa M. Mata, and Carlos A. V. Costa. "Education for Sustainability: Challenges and Trends". Clean Technologies and Environmental Policy 8 (2006): 31-37. doi: 10.1007/s10098-005-0026-3.

McKeown, Rosalyn. Education for Sustainable Development Toolkit, 2002. Accessed August 08, 2019. http://www.esdtoolkit.org/esd_toolkit_v2.pdf.

Микановић, Бране. “Исходи учења и стандарди знања у основном образовању”. Иновачије у настави 27 (2014): 84-93.

Милутиновић, Јована. “Појам циљева образовања и учења”. Педагошка стварност 53 (2007): 375-384.

Milutinović, Slobodan, and Vesna Nikolić. "Rethinking Higher Education for Sustainable Development in Serbia: An assessment of Copernicus Charter Principles in Current Higher Education Practices". Journal of Cleaner Production 62 (2014): 7-113. 
Минић, Весна и Марија Јовановић. “Еколошко васпитање и образовање у млађим разредима основне школе”. Зборник радова Филозофског факултета у Приштини 49 (2019): 125-144. doi:10.5937/ZRFFP49-21288.

Надић, Дарко. “Компаративна анлиза националних стратегија одрживог развоја Републике Србије, Црне Горе и Хрватске”. Теме 36 (2012): 501-523.

Николић, Весна и Љиљана Ђуровић. "Циљеви и задаци еколошког васпитања и образовања кроз призму Блумове операционализације”. Теме 36 (2012): 561-579.

Nikolić, Vesna, Boban Milutinović, Pece Nedanovski, and Kornelija Mrnjaus. "ESD Professional Development of University Educators in Serbia, Croatia and Macedonia: A Comparative Analysis". Journal of Cleaner Production 18 (2017): 923-938.

Николић, Весна. “Образовање за одрживи развој”. У Путоказ ка одржсиом развоју: национална стратегија одржсивог развоја, уредила Даринка Радојевић, 120-147. Београд: Министарство за науку и технолошки развој, Кабинет потпредседника Владе за европске интеграције, 2011.

“Odluka o donošenju kurikuluma za međupredmetnu temu Održivi razvoj za osnovne i srednje škole u Republici Hrvatskoj”. Narodne novine 7/2019. Accessed August 09, 2019. https://narodne-novine.nn.hr/clanci/sluzbeni/ 2019_01_7_152.html.

Орловић-Ловрен, Виолета. "Универзитетски наставници у транзицији ка одрживом развоју: један концепт и бројна питања”. Иноваџије у настави 29 (2016): 123-139. doi: 10.5937/inovacije16041230.

Osman, Amina, Sultana Ladhani, Emma Findlater, and Veronica McKay. Curriculum Framework for the Sustainable Development Goals. Commonwealth Secretariat, 2017. Accessed July 02, 2019. https://www.thecommonwealtheducationhub.net/wp content/uploads/2017/01/Curriculum_Framework_for_SDGs_July_2017.pdf.

“Правилник о допуни правилника о наставном плану и програму стручних предмета средњег стручног образовању у подручју рада Хемија, неметали и графичарство”. У Службени гласник РС 12/2015.

“Правилник о допуни правилника о наставном плану и програму стручних предмета средњег стручног образовању у подручју рада Шумарство и обрада дрвета". У Службени гласник РС 6/2015.

“Правилник о изменама правилника о наставном плану и програму за стицање образовања у трогодишњем и четворогодишњем трајању у стручној школи за подручје рада електротехника". У Службени гласник PC 13/2013.

“Правилник о изменама правилника о наставном плану и програму за стицање образовања у трогодишњем и четворогодишњем трајању у стручној школи за подручје рада Хемија, неметали и графичарство”. У Службени гласник РС 10/2013.

“Правилник о измени и допунама правилника о наставном плану и програму средњег стручног образовања у подручју рада Економија, право и администрација”. У Службени гласник РC 15/2015.

„Правилник о Националном оквиру образовања и васпитања“. У Службени гласник РС 98/2017.

"Правилник о наставном плану и програму огледа за образовни профил Мехатроничар за радарске системе". У Службени гласник РС 8/2010.

"Правилник о наставном плану и програму стручних предмета средњег стручног образовању у подручју рада Геологија, рударство и металургија”. У Службени гласник РС 5/2017.

“Правилник о плану и програму наставе и учења стручних предмета средњег стручног образовања у подручју рада Геодезија и грађевинарство”. У Службени гласник РС 7/2018.

"Правилник о плану и програму наставе и учења стручних предмета средњег стручног образовању у подручју рада Хемија, неметали и графичарство”. У Службени гласник РC 14/2018.

“Правилник о плану наставе и учења за пети и шести разред основног образовања и васпитања и програму наставе и учења за пети и шести разред основног образовања и васпитања”. Службени гласник РС У Службени гласник РС 15/2018.

"Правилник о плану наставе и учења за први циклус основног образовања и васпитања и програму наставе и учења за први разред основног образовања и васпитања". У Службени гласник РС 10/2017.

“Правилник о Програму наставе и учења за четврти разред основног образовања и васпитања". У Службени гласник РС 11/2019.

“Правилник о Програму наставе и учења за други разред основног образовања и васпитања”. У Службени гласник РС РС 16/2018.

“Правилник о програму наставе и учења за осми разред основног образовања и васпитања". У Службени гласник РC 11/2019.

“Правилник о Програму наставе и учења за први разред гимназије”. У Службени гласник РС 12/2018.

“Правилник о Програму наставе и учења за седми разред основног образовања и васпитања”. У Службени гласник РС 5/2019.

“Правилник о програму наставе и учења за трећи разред основног образовања и васпитања У Службени гласник РС 5/2019. 
Raditya-Ležaić, Anastasya, Ana-Maria Boromisa i Sanja Tišma. "Komparativni pregled obrazovanja za održivi razvoj i istraživanje potreba za stručnjacima u Hrvatskoj”. Socijalna ekologika 27 (2018): 165-180. doi: 10.17234/SocEkol.27.2.3.

Sherren, Kate. "Balancing the Disciplines: A Multidisciplinary Perspective on Sustainability Curriculum Content." Australian Journal of Environmental Education 21 (2005): 97-106. doi: 10.1017/S0814062600000987.

Stanišić, Jelena M. "Characteristics of Teaching Environmental Education in Primary Schools". Inovacije u nastavi 29 (2016): 87-100. doi: 10.5937/inovacije1604087S.

UN. Agenda 21, 1992. Accessed July 01, 2020. https://sustainabledevelopment.un.org/outcomedocuments/agenda21

UNECE. The Development of the Regional Strategy on Education for Sustainable Development, 2005a. Accessed August 01, 2019. http://www.unece.org/environmental-policy/education-for-sustainable-development/aboutthe-strategy-for-esd/the-strategy.html.

UNECE. UNECE Strategy for Education for Sustainable Development, 2005b. Accessed August 05, 2019. $\mathrm{http} / / / \mathrm{www}$.unece.org/environmental-policy/education-for-sustainable-development/about-the-strategy-foresd/the-strategy.html.

UNESCO. Education for Sustainable Development Goals: Learning Objectives. Paris, France: United Nations Educational, Scientific and Cultural Organization, 2017.

UNESCO. Education for Sustainable Development Sourcebook. Paris, France: United Nations Educational, Scientific and Cultural Organization, 2012.

Veinović, Zorica. "Environmental Impact of Consumerism from the Perspective of the Social, Environmental and Scientific Education”. Inovacije u nastavi 29 (2016): 72-86. doi: 10.5937/inovacije1604072V.

Веиновић, Зорица. “Образовање учитеља и одрживи развој”. У Имплементација иновација у образовању и васпитағу - изазови и дилеме, уредили Јасмина Милинковић и Биљана Требјешанин, 571-586. Београд: Учитељски факултет, 2015.

Veinović, Zorica. "The Curricula Revision in the Context of Education for Sustainable Development: From the Perspective of Two Primary School Subjects' Curricula”. Zbornik Instituta za pedagoška istraživanja 49 (2017): 191-212.

Vidojević, Jelena. “Obrazovanje za održivi razvoj”. U Univerzitet i održivi razvoj, uredio Čedomir Čupić, $141-161$. Beograd: Fakultet političkih nauka Univerziteta u Beogradu i Centar za ekološku politiku i održivi razvoj, 2011.

Влада Републике Србије. Национална стратегија одрживог развоја, 2008. Accessed July 14, 2020. http://www.zurbnis.rs/zakoni/Nacionalna\%20strategija\%20odrzivog\%20razvoja.pdf

Vukelić, Nena. "Odrednice spremnosti (budućih) nastavnika na obrazovanje za održivi razvoj”. Napredak 161 (2020): 141-161.

Вукић, Тамара. “Одрживи развој као иновација у наставним плановима и програмима”. У Иновативни приступ васпитању и образовању: стање, дилеме и преспективе. уредиле Љиљана Пауновић и Слађана Видосављевић, 381-396. Лепосавић: Учитељски факултет у Призрену - Лепосавићу, 2019.

WCED. Our Common Future, 1987. Accesed July 16, 2020. https://www.are.admin.ch/are/en/home/sustainabledevelopment/international-cooperation/2030agenda/un-_-milestones-in-sustainable-development/1987--brundtlandreport.html

Woo, Yoke Ling, Mazlin Mokhatar, Ibrahim Komoo, and Azman Norzaini. "Education for Sustainable Development: A Review of Characteristics of Sustainability Curriculum". OIDA International Journal of Sustainable Development 3 (2012): 33-43.

\section{CILJEVI I ISHODI OBRAZOVANJA ZA ODRŽIVI RAZVOJ U SRBIJI, CRNOJ GORI I HRVATSKOJ KAO INOVACIJE SAVREMENOG KURIKULUMA}

Obrazovanje za održivi razvoj, kao imperativ vremena, postalo je sastavni deo kurikuluma u mnogobrojnim obrazovnim sistemima. U fokusu rada je obrazovanje za održivi razvoj obrazovnih sistema Crne Gore, Hrvatske i Srbije, sa posebnim osvrtom na ciljeve i ishode obrazovanja za održivi razvoj. Nakon predstavljanja specifičnosti održivog razvoja na osnovnoškolskom i srednjoškolskom nivou obrazovnih sistema ovih zemalja, izvršena je komparativna analiza ciljeva i ishoda u okviru kurikuluma izbornog programa Obrazovanje za održivi razvoj u Srbiji, međupredmetne oblasti Obrazovanje za održivi razvoj u Crnoj Gori i međupredmetne teme Održivi razvoj u Hrvatskoj. Komparativnim prikazom utvrđeno je da su ciljevi obrazovanja za održivi razvoj u sva tri slučaja usmereni na razvijanje aktivnog i odgovornog odnosa učenika prema drugim ljudima, životnoj sredini, 
uzimajući u obzir perspektivu budućnosti, kao i da su ciljevi i ishodi obrazovanja za održivi razvoj u Crnoj Gori i Hrvatskoj obuhvatniji i sadržajniji u odnosu na ciljeve $i$ ishode izbornog programa Obrazovanje za održivi razvoj u Srbiji. I pored toga što ciljevi i ishodi novog izbornog programa, međupredmetnih tema i međupredmetnih oblasti koje su specifično orijentisane na održivi razvoj predstavljaju inovaciju kurikuluma u Srbiji, Crnoj Gori i Hrvatskoj, njihovo definisanje je samo polazna osnova za aktivnosti usmerene ka obrazovanju učenika za život i rad u savremenom društvu pred kojim se postavlja zahtev da postane održivo.

Ključne reči: obrazovanje za održivi razvoj, kurikulum, Srbija, Crna Gora, Hrvatska. 